\title{
Revistas: Orgulho da FEBRASGO
}

Femina, a "Primeira Dama" da Ginecologia e Obstetrícia Brasileira, é a fonte mais utilizada nacionalmente pelos colegas que buscam informações na área. Nela existem artigos de revisão assinados por renomados colegas que possibilitam, de forma rápida e com seriedade científica, atualização constante.

A Revista Brasileira de Ginecologia e Obstetrícia (RBGO), nasceu para preencher um espaço onde os sócios pudessem divulgar os resultados de suas pesquisas. É através dela que ficamos conhecendo as linhas e o que pesquisam os diferentes serviços, e quem publica e o que é publicado. Tudo isto nos possibilita confrontar o que estudamos e fazemos, ou seja, a nossa experiência com outras similares.

As nossas duas Revistas, isto é, a Femina e a RBGO, se complementam na função de manter atualizados os conhecimentos dos sócios da FEBRASGO. E delas muito nos orgulhamos!!!

\section{A Diretoria}

